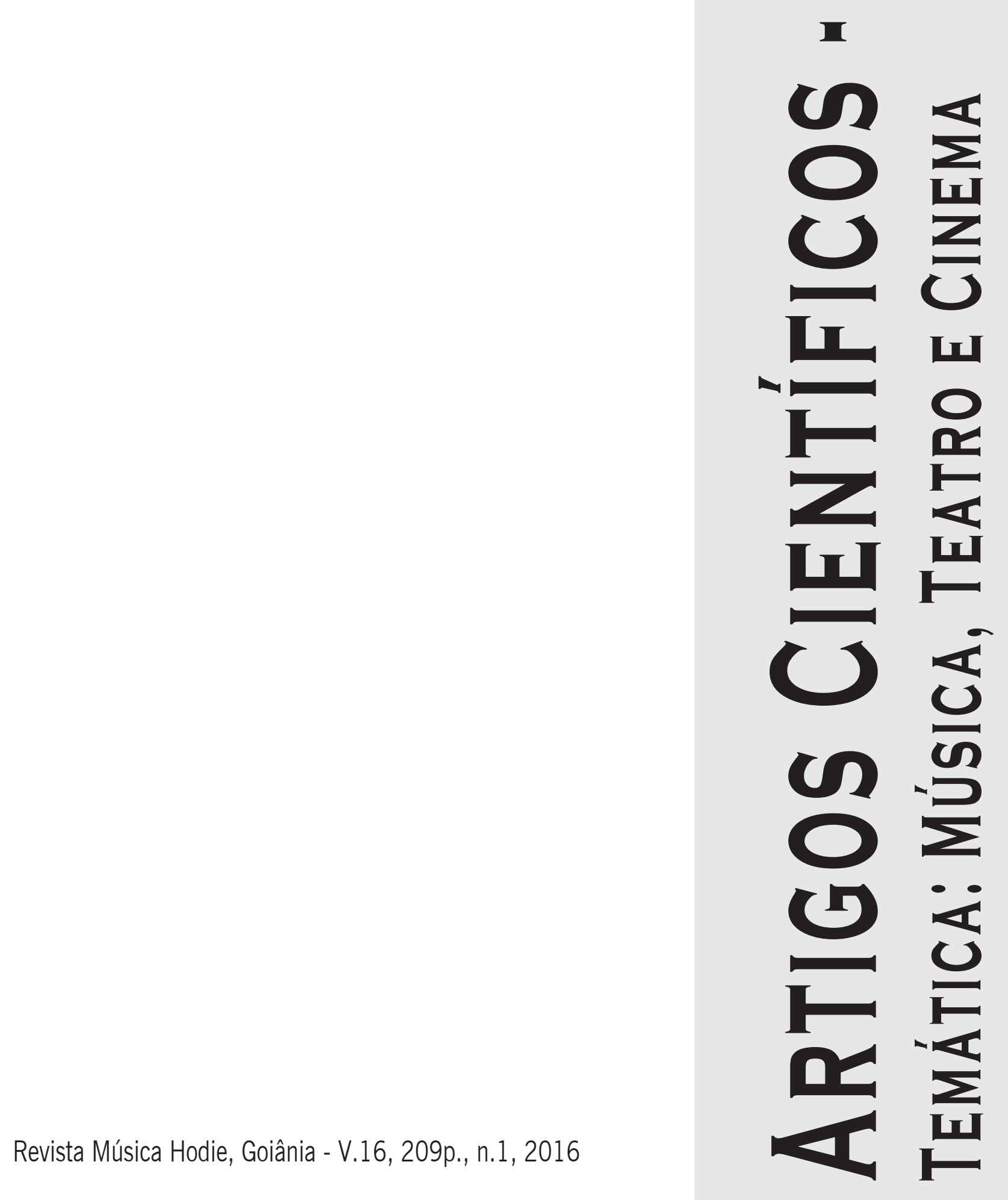




\title{
Giuseppe Millico and La pietà d'amore: from Naples to Lisbon to Rio de Janeiro
}

\author{
David Cranmer (FCSH/Universidade NOVA de Lisboa, Lisbon, Portugal)
} cranmer@netcabo.pt

\begin{abstract}
Giuseppe Millico, best known in his time as a castrato singer and to posterity for his connections with Christoph Gluck, was also a composer of songs and dramatic works. This article traces the career of one of the latter, the pastoral drama La pietà d'amore. It was first performed in Naples in 1782, where, unusually, it was also published. It subsequently came to be staged in Lisbon, the following year, and at the Ópera Nova Theatre, Rio to Janeiro, probably in 1786. In addition, certain aspects of the preface to the printed edition are considered, as well as manuscript scores and libretti relating to the known productions.
\end{abstract}

Keywords: Giuseppe Millico; La pietà d'amore; Ópera Nova; Ajuda; Antonio Lucchesi.

Giuseppe Millico e La pietà d'amore: de Nápoles a Lisboa ao Rio de Janeiro

Resumo: Giuseppe Millico, célebre no seu tempo como cantor castrato e conhecido pela posteridade sobretudo devido às suas ligações com Christoph Gluck, foi igualmente compositor de canções e obras dramáticas. Este artigo debruça-se sobre a disseminação de uma destas últimas, o drama pastoral La pietà d'amore. Estreou-se em Nápoles em 1782, onde, inusitadamente, também foi editada. Veio a ser encenada em Lisboa, no ano seguinte, e na Ópera Nova, no Rio de Janeiro, provavelmente em 1786. Serão abordados adicionalmente diversos aspectos do prefácio da edição impressa, para além de partituras manuscritas e libretos relacionados com as produções conhecidas.

Palavras-chave: Giuseppe Millico; La pietà d'amore; Ópera Nova; Ajuda; Antonio Lucchesi.

Giuseppe Millico y La pietà d’amore: de Nápoles a Lisboa a Río de Janeiro

Resumen: Giuseppe Millico, conocido en su tiempo como castrato y cuyo nombre ha llegado a la posteridad principalmente por causa de sus conexiones con Christoph Gluck, fue compositor tanto de canciones como de obras dramáticas. El presente artículo se dedica a la diseminación de una de estas últimas: el drama pastoral La pietà d'amore. Fue estrenada en Nápoles en 1782, donde fue, inusitadamente, también editada. Esta pieza fue así mismo puesta en escena en Lisboa el año siguiente y en la Ópera Nova de Río de Janeiro, probablemente en 1786. A lo largo del presente se va a hacer referencia adicionalmente, a diversos aspectos del prefacio de la edición impresa, así como a partituras manuscritas y libretos relacionados con las producciones conocidas.

Palabras clave: Giuseppe Millico; La pietà d'amore; Ópera Nova; Ajuda; Antonio Lucchesi.

\section{Opening remarks}

The career of the castrato soprano singer Giuseppe Millico (1737-1802) illustrates particularly well how different musicologies can view the same object from different perspectives. The dramatic work La pietà d'amore, first performed in Naples, in 1782, the composition of interest to us here, was remarkable for a number of reasons, not least because it was published there the same year in full score - something almost unheard of in eighteenth-century Italy, where both operas and smaller works circulated largely in manuscript copies. For this edition, following a dedication to the librettist, Don Antonio Lucchesi, Millico wrote a six-page preface, which, among other things, praises the musical-dramatic innovations of Christoph Gluck. It is precisely Millico's Gluck connection that tends to be emphasised in standard reference works and in Austro-German musicology. ${ }^{1}$ For Italians, on the other hand, particularly important is the fact that he was born in the Kingdom of Naples and returned there after a successful career in other parts of the Italian peninsula and beyond it. ${ }^{2}$ His significance is quite different, however, when seen from a Luso-Brazilian perspective. Here La pietà d'amore is absolutely central, and not because of the preface (informative though it certainly is) but because the only known non-Italian productions took 
place in Lisbon and Rio de Janeiro, and because otherwise Millico's connection with metropolitan and colonial Portugal is marginal and fortuitous. ${ }^{3}$ This article, therefore, while it begins by presenting certain aspects of the singer-composer's life and career, including his links with Gluck, focuses primarily on what is known of the circumstances of the drama's composition and the subsequent productions.

\section{The composer's career prior to La pietà d'amore}

Vito Giuseppe Millico was born on 19 January 1737 at Terlizzi, near Bari, in the region of Apulia, the heel of the Italian peninsula, at that time part of the Spanish Bourbon kingdom of Naples. ${ }^{4}$ It is presumed that he studied at one of the Neapolitan conservatories, following which he gave his debut in Rome in 1757. From 1758 to 1765 he sang at the Russian court, including during the troubled times of Catherine the Great's rise to power.

His links with Christoph Gluck began at Parma in 1769, when the latter prepared the extensive occasional dramatic work Le feste d'Apollo for the marriage of the Bourbon Duke Ferdinand of Parma (first cousin of the King of Naples) and Maria Amalia of Austria, incorporating part of his opera Orfeo ed Euridice. Since the original Orfeo, Gaetano Guadagni was a contralto, Gluck adapted the vocal line to suit the higher voice of Millico. As a consequence of this experience, Gluck invited him to Vienna the following year, rewriting Orfeo ed Euridice with his voice in mind, and similarly adapting Alceste for a new production. Millico also sang the role of Paride in the premiere of Paride ed Elena the same year.

From 1772-74 he was based in London though he also travelled from there to other centres on the continent. While in London, he took part in, among other operas, the production of Gluck's Orfeo ed Euridice in 1772, as well as becoming friends with the family of the music historiographer Charles Burney. Burney's daughter, the novelist Frances ("Fanny") Burney, in her first novel, Evelina, makes her heroine take great delight in the singing of Millico at the opera, only for both the singer and herself to be made objects of ridicule by her rather uncultured companions. ${ }^{5}$ During his years in London, Millico also published two sets of canzonette, though it is unclear whether these were composed in London, or some, at least, before he had arrived (MILLICO, 1773 and 1774).

In the years that followed, prior to his definitive return to Naples, he travelled extensively, singing in Paris, Mannheim, Schwetzingen and Zweibrücken, as well as major opera centres in Italy - Venice, Milan, Florence and Rome. In Naples, where he settled at some point between 1777 and 1779, ${ }^{6}$ he was appointed "Virtuoso di Camera e della Regia Cappella” and Music Master to the Royal Princesses. His public performances as a singer, however, came to an end within a few years ${ }^{7}$ and Millico dedicated his last years primarily to composing and teaching (singing and composition).

Moving, as he did, within court and aristocratic circles, he quickly became involved in the cultural activities of the Prince of Campofranco, Antonio Lucchesi Palli (17161803). A military man and administrator, much favoured by the Neapolitan royal family, the Prince was also a poet of considerable learning and taste, and both consumer and defender of French thinking, particularly that of Rousseau.

From the preface to La pietà d'amore we learn that this was the third composition that Lucchesi had commissioned from Millico. All were to poetic texts that the Prince himself had written. The first of these was a brief cantata for a single voice entitled Il pianto d'Erminia (CAPRIOLI, 2010), ${ }^{8}$ composed to lament the death (22 February 1780) of the child 
Princess Marianna, aged barely 4 years and 3 months, victim of smallpox. To judge from the libretto (LUCCHESI PALLI, 1795: v 2, 27-30), it consisted of just two recitatives each followed by an aria.

The more ambitious cantata for four voices, Angelica e Medoro, has given rise to a certain amount of confusion. Gerhard Croll's entry in the New Grove Dictionary of Opera (CROLL 1992), for example, gives the librettist as Metastasio, the date as "1783?" and a reference to the collaboration of Cimarosa. However, Lucchesi's text is quite different from Metastasio's libretto of this title, being more compact and for fewer characters (LUCCHESI PALLI, 1795: v 2, 31-48); Millico not only reinforces Lucchesi's authorship, in his preface to La pietà d'amore (MILLICO, 1782: [iv]), but the very fact that he mentions the work there serves to prove that it must have been composed before, not after, the latter (1782); and none of the surviving manuscript scores of this cantata makes any reference to Cimarosa, ${ }^{9}$ so that, although Cimarosa was in Naples at about the time we might suppose it was composed (for the premiere of L'amante combattuto dalle donne di punto, at the Teatro de' Fiorentini, in Spring 1781), there is no obvious reason to link this presence with the composition of Angelica e Medoro.

To some extent this cantata is a conventionally pastoral work, but it is unusual in its textures and timbres. All four solo voices are written in the C1 clef (with varying vocal ranges), though the four-part chorus is written for SATB. There is no recitativo secco at all but each main number is preceded by a more or less lengthy accompanied recitative with arioso sections and musically dramatic moments, reflecting the meaning of the text. Angelica's two solo numbers each have an obbligato instrumental solo - a cavatina with harp (an instrument at which Millico himself was particularly skilled) and an aria with oboe. The recitativo-arioso preceding Orlando's aria has passages for two horns and later a solo bassoon obbligato. In general, in the recitative-arioso sections the frequent use of repeated notes in the strings (groups of four and even whole bars of repeated semiquavers) is quite striking, with two actual tremolo passages.

\section{La pietà d'amore}

Turning, then, to La pietà d'amore itself, dramatically and musically it is a more fully developed and ambitious work than its predecessors. At the same time it follows in the same footsteps in the sense that it is a pastoral drama with music rather than an opera in the true sense, and is divided, like a serenata, in two parts, not in acts. The librettist designated it as a cantata for 5 voices (LUCCHESI PALLI, 1795: v 2, 49).

There are five characters: Orosmane (Prince of Sylphs), Morgana (a sorceress), Climene (a princess), Azem (a prince) and Amore, an allegorical deus ex machina. There are also choruses of sylphs, spirits and shades. The plot is a simple, conventional one. Climene, through Morgana's intervention, has been kidnapped by Orosmane for his bride. Azem searches for her, but on finding her is led off by evil spirits to cross the river Styx. The shades refuse to take him. Amore brings him back to life. Orosmane is brought down. Azem is restored to Climene (LUCCHESI PALLI, 1795: v 2, 49-80).

As in Angelica e Medoro, it is divided into scenes, which tend to be monologues, consisting almost entirely of orchestrally accompanied recitatives and arioso passages, sometimes including an obbligato oboe as well as strings, and a series of arias. There are some recitativo secco sections, but they are short and few in number. There is just one duet (for Climene and Azem), six chorus interventions and a closing vaudeville finale involving 
the five characters. Again as in Angelica e Medoro, all of the solo voices are written in a C1 clef and the chorus is a four-part one (SATB). As well as strings (once again often with repeated notes and occasional tremolo passages), there are paired flutes, oboes, clarinets, bassoons and horns, but though woodwind obbligati are a regular feature in the arias, the upper woodwinds never play together except in the finale (MILLICO, 1782).

Millico's preface is frustrating in that it tells us nothing about the circumstances of performance. Caprioli (2010) supposes, because of the librettist's designation "cantata”, that it was sung (but not staged) at the Teatro de' Fiorentini, without, however, giving any exact date. This designation, as well as its serenata-like qualities when taken as a dramaticmusical whole, certainly implies that it was an occasional work, intended, in principle, for performance at a royal/aristocratic wedding, birthday or name-day. As there were no dynastic marriages at that time, either in the Neapolitan Royal Family or in the Prince of Campofranco's own, and given that Millico dated his preface 15 June 1782, the most likely occasion would be St. Anthony's Day, the Prince's name-day just two days before, on 13 June (possibly celebrated the previous evening, as in Lisbon and Padua).

Unlike operas, however well received, occasional works, by their nature as works conceived for specific celebrations, were rarely repeated outside their original context. La pietà d'amore must have been perceived to be exceptional, therefore, for not only, as we have seen, was it published, but it received at least four subsequent performances, two in Italy (once again in Naples, and in Padua) and two outside (in Lisbon and in Rio de Janeiro).

How far the publication of the score was responsible for the subsequent performances and how far, from the outset, there was also circulation of manuscript copies is unclear, for though the Lisbon and Rio de Janeiro productions certainly used manuscript copies (which have survived), they may, in both instances, have been copied from either another manuscript or from the printed edition. What is certain, however, is that La pietà d'amore reached Lisbon with remarkable speed. Typically at this period, operas, circulating through the regular channels took about three or more years to reach Lisbon following a première in Italy, arriving more quickly only through specific means, such as newly-contracted singers. ${ }^{10}$ How this score reached Lisbon is unknown, but it was staged at the Ajuda Theatre on 18 December 1783, Queen Maria's name-day (Nossa Senhora do Ó - Our Lady of the $O$ ), only about 18 months after we suppose the premiere to have taken place. Seemingly, this was its first actual staging (as opposed to a 'concert version' as a cantata). It was, nevertheless, performed to celebrate a particular dynastic occasion and was not simply a routine new production.

The singers were Carlo Reyna (Orosmane), Giovanni Ripa (Climene), Vincenzo Marini (Azem), Fedele Venturi (Morgana) and Giuseppe Romanini (Amore) - all castrati (LUCCHESI PALLI, 1783). Certain adaptations were made to the score. In Part I Morgana's recitative and aria, in Scene 3, were cut, as was the Chorus in Scene 4. In Part II the vaudeville finale was reduced to a single general chorus. The SATB chorus was replaced by a four-voice chorus with three parts written in a C1 clef and one in C4. As the court orchestra had no clarinets, the clarinet parts were rewritten for oboes (Part I, Scenes 6-8 and Part II Scene 9) or for bassoons (Part 2, Scenes 7-8). ${ }^{11}$

The two subsequent Italian revivals took place the following year, privately at the Naples Royal Palace with a repeat at the Palace of the Russian Ambassador, Prince A. K. Rasumovsky (CAPRIOLI, 2010), and at a private accademia in Padua. The libretto of the latter was printed in 1783 but states that performance was to take place in 1784 . That would imply a printing at the year-end in readiness for performance early the following year. 
It has not proved possible to ascertain the exact dates of the performances in Naples. To judge from the text printed in the librettist's Poesie (LUCCHESI PALLI, 1795: v 2, 49-80), certain minor alterations were made for this revival. The aria originally sung by Climene in Part I Scene 5 is brought forward to conclude Scene 2, leading to the cutting of all of the original Scene 5. There are also revisions to Part I Scene 4, Part II Scene 1 (a substantial addition to the recitative) and the chorus in Part II Scene 9.

\section{The Rio de Janeiro production}

The production of La pietà d'amore in Rio de Janeiro has long been known of. It is referred to, for example, (as Piedade de amor) by Moreira e Azevedo, as early as 1877 (v 2,141 ), though it is only recently that the document he used (but without identifying his source) has become generally known (MENESES, s.d.). Millico's work is included in a list of opera titles (without reference to the respective composers) performed during the years that Luís de Vasconcelos e Sousa was Viceroy of Brazil (1778-90). At that time the only theatre functioning on a regular basis in Rio was the so-called "Ópera Nova", which belonged to Manuel Luiz Ferreira. ${ }^{12}$ As the document informs us, the company was run by António Nascentes Pinto and

among the singers who distinguished themselves at that time was Pedro, coming from Portugal, who was at the same time an excellent dramatic actor and poet, author of several comical entremezes: $:^{13}$ his companions were Manuel Ro[drigue]s da Silva, Lobato, Ladislau Benavenuto, a comic buffo, José Inácio da S.a [Silva/Sousa] Costa (MENESES, s.d.). ${ }^{14}$

A number of manuscript scores and parts (mostly instrumental) from the Ópera Nova have survived and are conserved in the Musical Archive of the Ducal Palace, Vila Viçosa, in Portugal..$^{15}$ Among these is the full score of La pietà d'amore, instrumental parts and some of the vocal parts. ${ }^{16}$ The various hands of the copyists in this material are fully compatible with a dating at some point in the 1780s. A number of features are particularly striking. Firstly, it retains what is essentially the original version, including the use of clarinets - not only are they present in the score, but the clarinet parts are among those preserved. This is probably the earliest unequivocal proof of the use of clarinets in Rio de Janeiro, several years before they were in use in Lisbon. ${ }^{17}$ Furthermore, there is a reference in the flute part, immediately before Azem's aria in Part I to "Rec[itativ]o de clarineta de Pedro" ("Pedro's clarinet recitative"), confirming the participation of the Portuguese Pedro - Pedro António Pereira. His vocal part also survives. ${ }^{18}$ The original C1 clef is retained, though he was a tenor - doubtless, he just sang it an octave below - but the text has been translated into Portuguese, as is the case also in the surviving fragments of chorus parts. Manoel Joaquim Meneses (s.d.) also makes reference to the need to translate Italian operas into Portuguese at this time.

There remain two important questions. How did La pietà d'amore get to Rio de Janeiro and when exactly was it performed - and, assuming it was for a special occasion, then which? It is clear that of the various manuscript works from the Ópera Nova preserved at the Ducal Palace, Vila Viçosa, some were copied locally in Rio de Janeiro while others came originally from Lisbon. Admittedly at a later date, in one instance - Paisiello's La modista raggiratrice - we can show (because, uniquely, the names of the respective singers are written on the vocal parts for both productions) that the surviving material was first used at the 
royal theatre at Salvaterra (Portugal) in 1792 and subsequently at the Ópera Nova around 1808 (CRANMER, 2009, 108-109). Given the very limited distribution of subsequent productions of La pietà d'amore, we may reasonably suppose, therefore, that this too reached Rio from the Portuguese royal theatres. ${ }^{19}$

With regard to the second question, though we have no direct documentary evidence for it, there is an obvious candidate for date and occasion, given the nature of the plot, in which love triumphs over all adversaries. On 8 May 1785 Prince João (Queen Maria's $2^{\text {nd }}$ son) and the Spanish Bourbon Princess Carlota Joaquina were married..$^{20}$ Celebrations were held throughout metropolitan Portugal and the Empire. In Rio de Janeiro the city council organised lavish festivities in January and February 1786, coming to a peak on 2 February. Among these were performances of opera (LARA, 2007: 106), though no title is given. I would suggest that the production of La pietà d'amore is likely to have taken place within this context.

\section{Closing remarks}

As we have seen, given the very limited number of revivals it received, it is curious that Millico's work not only reached Lisbon and Rio de Janeiro, but actually received performances there. It should be mentioned, in passing, that there is also a manuscript of Climene's aria from Part I among the many opera arias used for pedagogic purposes in Lisbon's Patriarchal Seminary. ${ }^{21}$ It is a late copy, from the first decade of the nineteenth century, and wrongly attributed to Valentino Fioravanti, but that a copy should have been made some 20 years after its performance in Lisbon indicates a continued interest in this music.

Giuseppe Millico was a Neapolitan national; he was associated with Gluck; but he was also surprisingly important in the Luso-Brazilian world.

\section{Notas}

1 For example, FINSCHER (1975), BRANDENBURG in MGG (1994-2008).

2 For example, BELLUCCI LA SALANDRA (1951). CAPRIOLI (2010) provides a strikingly well-researched dictionary entry for Millico's Italian activity but does so at the expense of references to his appearances in the Germanspeaking world between his departure from London and his settling in Naples.

3 It should just be mentioned, however, that the Biblioteca Nacional de Portugal possesses three of his published song collections, namely A third sett of six canzonets with an accompanyment for the pedal or small harp, forte piano, or harpsichord. London: Longman and Broderip, [1786], A fourth sett of six canzonets [...]. London: Longman and Broderip,[1788], and Six Songs, with an accompanyment for the great or small harp, forte piano or harpsichord, etc. London: R. Bremner, [1780?], as well as a manuscript of the cavatina "Ho sparso tante lagrime", copied in Lisbon probably c. 1800.

4 The King of Naples, Ferdinand IV, was also King of Sicily, but the two kingdoms were only formally united after the Napoleonic occupation.

5 BURNEY (1778), letter 21.

${ }^{6}$ He sang in Giuseppe Sarti’s Ifigenia in Aulide and Pietro Guglielmi's Artaserse, in Rome, during the Carnival season 1777. As we see below, he composed a cantata following the death of Princess Marianna, which was in February 1780. Presumably, to have received this commission, he must already have been established in Naples for at least a few weeks.

7 CAPRIOLI (2010) informs us that his last public performance took place in 1783.

8 LUCCHESI PALLI (1795), v. 2: 27 just gives the more generic title Sentimenti di tenerezza in occasione della morte della principessa D. Marianna.

9 At least three manuscript copies survive, one at the Conservatorio Giuseppe Verdi, Milan (call-mark 2-F-11), one at the British Library, London (call-mark R.M.22.h.9) and one at the University of North Carolina Music Library, 
Chapel Hill (no call-mark), the last of which is available online: http://petrucci.mus.auth.gr/imglnks/usimg/e/e1/ IMSLP311799-PMLP503652-angelicaemedoroc00mill_0.pdf (last consulted 15/01/2016). The Milan copy attributes the work to Pietro Guglielmi, but this is clearly a lapse, in a late copy (dated 1802). The British Library and UNCML copies are unequivocal in ascribing the work (solely) to Millico. A copy of the recitative and duet from scene 7, "Come mai lasciar", at the Santini-Bibliothek, Münster (call-mark SANT Hs 2685) also indicates Millico as the composer.

10 The castrato singer Vincenzo Marini was newly contracted in Lisbon in 1783, but it has proved impossible to find out anything about his whereabouts immediately prior to this and, therefore, whether he might have brought the score with him.

11 The score (2 volumes) relating to this production is to be found at the Ajuda Palace Library, Lisbon, with the callmark 45-I-23 and 24.

${ }^{12}$ For this reason it is also known as the "Teatro de Manuel Luiz".

${ }^{13}$ One-act comical plays performed in intervals of the main work of the evening and/or at the end of the show.

${ }^{14}$ Author's translation. The original, with abbreviations expanded and orthography modernised reads: "entre os cantores daquele tempo distinguia um de nome Pedro, vindo de Portugal, que era ao mesmo tempo excelente actor dramático, e poeta, compositor de alguns entremezes jocosos: eram seus companheiros M[anu]el Ro[drigue] s Silva, Lobato, Ladislau Benavenuto, cómico buffo, José Inácio da S.a [Silva/Sousa] Costa, e outros.”

15 They were probably brought to Portugal by King João VI, when the Portuguese Royal Family returned from Brazil to Portugal in 1821. Rio de Janeiro had been the Portuguese capital for more than 13 years, following the transfer of the Royal Family, court and administration there, in the wake of the $1^{\text {st }}$ French Invasion of Portugal in November 1807 (CRANMER, 2012: 566).

${ }^{16}$ Call-mark G prática 23, with some loose parts in G prática 117.63.

17 The earliest use in Lisbon, to the author's knowledge, is in António Leal Moreira's A saloia namorada, which, however, only makes use of one clarinet, not two as in La pietà d'amore.

18 In G prática 117.63.

19 Up to 1792 theatrical performances took place at three royal palaces. Salvaterra was used during the Carnival season, while at other times performances took place at Ajuda (as in the case of La pietà d'amore) or Queluz.

${ }^{20}$ Following the death of the Royal Prince José in 1788, João was to become heir to the throne: Prince Regent de facto in 1792, de jure in 1799 and, following Maria I’s death in 1816, King João VI.

${ }^{21}$ Biblioteca Nacional de Portugal, call-mark C.N. 103 N. ${ }^{\circ}$ 2, folios 25r-34v.

\section{Referências}

AZEVEDO, Manuel Duarte Moreira de. O Rio de Janeiro, sua história, monumentos, homens notáveis. Rio de Janeiro: Garnier, 1877.

BARBAGALLO, Francesco. Campofranco, Antonino Lucchesi-Palli e Gallego principe di. In: Dizionario Biografico degli Italiani, v. 17, 1974. http://www.treccani.it/enciclopedia/antonino-lucchesi-palli-e-gallego-principe-di-campofranco_(Dizionario_Biografico)/ (last consulted 15/01/2016).

BELLUCCI LA SALANDRA, Mario. Vito Giuseppe Millico (il Terlizzese): sopranista e compositore melodrammatico del Settecento. Bari: Alfredo Cressati, 1951.

BRANDENBURG, Irene. Millico, Vito Giuseppe. In: Die Musik in Geschichte und Gegenwart: Personenteil. Kassel: Bärenreiter/Metzler, 1994-2008, v. 12, p. 227.

[BURNEY, Frances]. Evelina, or the history of a young lady's entrance into the world. London: T[homas] Lowndes, 1778.

CAPRIOLI, Leonella Grasso. Millico, Vito Giuseppe. In: Dizionario Biografico degli Italiani, v. 74, 2010. http://www.treccani.it/enciclopedia/vito-giuseppe-millico_(Dizionario_Biografico)/ (last consulted 15/01/2016).

CRANMER, David. Os manuscritos de música teatral no Paço Ducal de Vila Viçosa - a ligação brasileira. In: Callipole: revista de cultura, n. 17, 2009. p. 101-118. 
. Ópera e música teatral no Rio de Janeiro no reinado de D. Maria I: uma fonte mal conhecida. In: As músicas luso-brasileiras no final do Antigo Regime: repertórios, práticas e representações, ed. Maria Elizabeth Lucas \& Rui Vieira Nery. Lisboa: Imprensa Nacional-Casa da Moeda, 2012. p. 557-569.

CROLL, Gerhard. Millico, (Vito) Giuseppe. In: The New Grove Dictionary of Opera. London: MacMillan, 1992, v. 3, 399-400.

FINSCHER, Ludwig. Der Opernsänger als Komponist. G. M. und seiner Oper "La pietà d'amore”. Opernstudien. Anna Amalia Abert zum 65. Geburtstag, ed. Klaus Hortschansky. Tutzing: Schneider, 1975. p. 57-90.

LARA, Sílvia Hunold. Fragmentos setecentistas: escravidão, cultura e poder na América portuguesa. São Paulo: Companhia das Letras, 2007.

[LUCCHESI PALLI, Antonio]. La pietà di amore dramma per musica per celebrare l'augustissimo nome di Sua Maestà Fedelissima Donna Maria I. Regina de Portogallo degli Algarvi, \&c. \&c. Li 18. Dec. 1783. [Lisboa]: Nella Stamperia Reale, [1783].

LUCCHESI PALLI, Antonio. Poesie. v. 2, Napoli: s.n, 1795.

MENESES, Manoel Joaquim de. Companhias líricas no Teatro do Rio de Janeiro antes da chegada da Corte Portuguesa em 1808. Manuscript, s.d., Rio de Janeiro, Arquivo Histórico do Museu Histórico Nacional, call-mark L.4.P. 2, n.20. Transcribed in BUDASZ, Rogério. Teatro e música na América Portuguesa: ópera e teatro musical no Brasil (1700-1822) - convenções, repertório, raça, gênero e poder. Curitiba: DeArtes/Universidade Federal do Paraná, 2008, apêndice 8, p. $248-249$.

MILLICO, Giuseppe. Six songs, with an accompanyment for the great or small harp, forte piano or harpsichord, etc. London: Welcker, [1773].

. Second sett of six songs with an accompanyment for the great or small harp, forte piano or harpsichord, etc. London: Welcker, [1774].

. La pietà d'amore drama messo in musica. Napoli: s.n., 1782.

David Cranmer - British in origin but resident in Portugal since 1981, is a musicologist, organist and teacher at the Faculty of Social Sciences and Humanites of the Universidade Nova de Lisboa. With a doctorate from the University of London, he is coordinator of Caravelas - Study Group for the History of Luso-Brazilian music and has worked on various aspects of music and theatre in Portugal and Brazil in the 18th and 19th centuries. Among other things, he is co-author (with Manuel Carlos de Brito) of Crónicas da vida musical portuguesa na primeira metade do século XIX (Lisboa: Imprensa Nacional - Casa da Moeda, 1990), author of Laudate Domino: introdução à música sacra (Lisboa: Paulus, 2009) and of Música no D. Maria II: catálago da coleção de partituras (Lisboa: Teatro Nacional D. Maria II/Bicho-do-Mato, 2015), as well as editor of Mozart, Marcos Portugal e o seu tempo (Lisboa: Edições Colibri/ CESEM, 2010), Marcos Portugal: uma reavaliação (Lisboa: Edições Colibri/CESEM, 2012), and of various opera and theatre-music scores. 